\title{
Indigenous Sustainable Development
}

This book was designed to address some specific questions that would aid understanding of indigenous concepts of sustainable development. This has involved some empirical and theoretical inquiries into the tricky concepts of culture, development, and sustainability. Since the goal was to update our understandings of development theory by interacting those with indigenous perspectives, the first large task was to understand the place of culture in the history of development thought. The next task was to update theories of development and culture by synthesizing them with indigenous thought.

This began with an assumption that to understand indigenous concepts of sustainable development, these must be politically, economically, and historically situated. Case studies of Maya, Andean, and Garifuna development ideas were undertaken towards this goal. Each of these case studies was embedded in a specific local political economy, but they did share a common attribute: a history of economic, political, and cultural marginalization. The ways that these local histories interacted with colonial domination, as well as more current global material and cultural flows, produced each of the ideas. That is, indigenous ideas of sustainable development were produced as deep cultural histories interacted with rights and environmental movements at both local and global levels. Indigenous ideas of sustainable development, of course, continue to change with such interactions. 
In the last chapter, interacting indigenous ideas with "Western" ideas of development led to some interesting tensions and insights. The relation between indigenous thought and sustainability was not overtly addressed, however. In this chapter, we will explore this relation specifically. A preliminary description would be something like this: indigenous cosmovision does not create a separation between the natural world and a human one. Therefore, equity in material and non-material forms, insomuch as it reduces the marginality of indigenous peoples, will bend economy, politics, and culture towards ecological sustainability. Once indigenous perspectives are given their appropriate weight, related ideas such as deep ecology, biocentrism, or de-growth take a less radical, more pragmatic, aura.

To understand the implications of indigenous ideas to sustainable development, it is important to avoid two countervailing tendencies. One of these ebbs towards discounting indigenous thought as being "not real" or an "invented tradition." The other tendency reifies, freezes, or essentializes indigenous ideas - framing them as immutable, time-transcendent, and unrelated to other modes of thought, such as modernity, that may corrupt them. In truth, indigenous tradition, just like any tradition, is at once rooted and mutable. This becomes most apparent when we consider the origins in indigenous sustainable development, address issues of essentialism, and then explore indigenous sustainable development and its possible implementation.

\section{Where Does Indigenous Sustainable Development Come From?}

A central concern of this book was to locate the cultural, political, and economic origins of indigenous sustainable development. Discerning this required the interpretation of "grassroots," "bottom-up," largely inductively devised indigenous theories of development. Although indigenous development has become popularized in recent decades, it is obviously not a new idea. Rather, ideas of indigenous development have materialized through deep histories of thought and experience. The ideas of progress, development, and human rights that are so often associated with "Western" or "enlightenment" thought are present in this history. So too are the remnants of historical experience of Spanish conquest and association with an "indigenous" identity that was created as an "other" to the Spanish. 
More recent histories of civil war, dispossession, marginalization, genocide, racism, and persecution are also included in this history.

Contact with Marxist and postcolonial thought as well as the anticolonial pedagogies and assertions of Friere and Fanon are traceable in the discourse and practice of Maya and Andean development programmes especially. Current discursive structures such as International Human Rights, and Indigenous Rights law, as well as interaction with indigenous and environmental movements, were cited as key factors that assisted the historical emergence of Maya, Garifuna, and Andean ideas of development. These ideas were equally born of involvement with local, communitylevel interactions with and oppositions to the impositions of externally devised development projects, whether they be from international companies, development organizations, or national governments. Indigenous sustainable development, then, is best described as an iteration of existing ideas from varying sources as they interact with the historical and current every-day experience of indigenous communities.

Indigenous sustainable development, this implies, is not a new idea in the sense that it has emerged in a pristine form that is unrelated to other modes of thought. It has an expansive history of engagement with ideas that stem from modernity and coloniality. It is a transmodern idea of development-that is, an idea that is not modern or traditional, but both. A look at the origins of the idea makes obvious the fictitiousness of an assumed binary that separates the modern from the traditional. Indigenous sustainable development represents an interpretation of development that is informed by indigenous culture and historical experience. It is not a pure idea of development that has emerged from some pristine "other" of modernity, however. It has been forged by a continual relationship between coloniality and modernity, as the colonized mind is articulated by the modern, which is, in turn, articulated by the colonized. They are not separate, but constituent parts of a transmodern cultural, political, and economic reality. Indigenous ideas of sustainable development emerge from this transmodern reality, but unlike the majority of such ideas, they favour the perspectives and knowledges of the historically marginalized.

Substantial critiques may be raised regarding Maya, Andean, Garifuna, and indigenous movements in general regarding a tendency towards the essentialism and romanticization of indigenous culture. If Maya culture is as egalitarian and as rooted in a deep integration with nature as members of El Centro tend to argue, it might be asked, then, why do indigenous people so regularly throw plastic, paper, and metal refuse out of the 
windows of cars and public buses? Why do tourists learn upon visiting the ancient Maya ruins at Copan that that civilization disappeared due to the severe environmental degradation it wrought on its local natural environment? Why does culture in Maya villages seem so patriarchal, and why are women severely underrepresented in communal mayorships? Maya culture does not reveal itself to the outside observer to revolve around the types of ideals that are encapsulated in the so-called Maya cosmovision. The same could be said of Garifuna and Andean traditions.

Certainly, it seems fair to say that all indigenous people do not display nature-centric, communal, and egalitarian tendencies. A responsible development practitioner or policymaker would be wise to think about this before funding or designing any development intervention. The carte blanche support of an indigenous group that makes such claims may not lead to intended consequences. If this cultural characterization is dishonest, an indigenous-run grassroots project that is intended to promote gender equality and environmental sustainability may fail to achieve its goals. Blind trust in the egalitarian and naturalistic tendencies of indigenous culture could lead to bad programmes and misplaced development assistance funds.

When confronting indigenous leaders regarding this issue, the answer one receives is as simple as it is uncontestable: indigenous people who diverge from ideals of environmentalism and egalitarianism, it is explained, have/had lost their way. They have/had lost touch with their culture and the wisdom of their ancestors. Patriarchy and disrespect for the natural environment, it is argued, are largely Spanish colonial imports, and preColumbian divergences from nature and equality were temporary departures from ingrained cultural traits. Such answers are inscrutable due to their tautology. But the asking of them might just miss the point of movements for indigenous sustainable development in general.

It should be clear from the account given in this book that claims that the people have "lost their way" are a way of saying that indigenous culture has been transformed in a climate of severe discursive inequality - that cosmovision has been dominated, and that this is not democratic, nor does it represent development. This cultural domination (along with its economic and political counterparts) is contested by indigenous movements as they attempt to move towards an ideal of pluralistic democracy. Such a democracy, in its ideal form, would ensure that all cultural knowledges, understandings, and identities carry the same persuasive force. The valorization of indigenous cosmovisions in Guatemala, Honduras, and Ecuador is a political project designed to counter cultural domination that 
maintains discursive and material inequities. It is not intended to maintain an "indigenous" culture in a pre-assumed frozen state.

These indigenous democratizing projects were born at an intersection. One of the metaphorical roads in this meeting brings a deep historical past which includes an egalitarian, nature-centric ethic, as well as divergences from this. It also includes a history of colonial marginalization. This road carries the past. The other road brings current thinking on topics such as the environment, indigeneity, human rights, and development. It also carries the material and cultural realities of conflict with international mining, extraction, or tourism interests, and various laws and/or development projects. This road carries the present.

Many of these concepts of the past and present have resonance at the crossroads at which indigenous development thought works, and the items which resonate exude the pitch of a local-centric, nature-centric, egalitarian, indigenous, and endogenous political project. It is the strength and depth of this resonance which is the item to be judged for its "authenticity"-not its relation to historical "fact." The essentialist question oversimplifies the claims and the project connected with indigenous politics in Latin America and elsewhere. It may be functional as a limited academic trope, but is of limited functional interest where policy choices, development projects, and political assertions are concerned.

The sustainable development projects described in this book are not so much concerned with the revival of indigenous culture. They are concerned with building new manifestations of indigenous culture as remnants of the past mix with ideas of the present. These new manifestations place emphasis on equity and respect for the natural environment. Practitioners and policymakers that wish to engage similar culture-based, indigenous-run organizations in the interest of collaborative development would benefit from considering such things. An indigenous organization that simply references the assertion of culture as its policy goal is different from one that also has programmes enacted that seek to promote environmental sustainability and gender equality. These types of markers are important when considering development assistance or political solidarity.

\section{What Is Indigenous Sustainable Development?}

But what, in the end, is the relation between indigenous culture and sustainable development? To answer this, it must first be understood that indigenous ideas of development resonate strongly with the group of ideas 
that were labelled cultural political economy (CPE) in this book-this includes more recent and less relativistic variants of post-development theory. At the very root of indigenous development theory is the depiction of humans as social subjects that are formed through discoursewhich also serves to make the social and material world intelligible. Such discourses also shape the materiality of the physical world as humans enact their cultural relation with their environment. The material environment simultaneously formats the range of possibility available to society and culture. Fundamental to indigenous sustainable development, then, is the inseparability of the material and the cultural-these are part of the same substance. Separation of them can occur for descriptive and analytical purposes, but this split should not be reified in the process. In indigenous thought, nature and culture are one. Indigenous thought posits a similar relationship between the individual subject and larger community. Individual subjects, with their range of beliefs, tastes, and values, are produced socially and communicatively. One may be able to pull the individual apart from the social temporarily for descriptive or analytical purposes, but the fact that they belong to one substance should not be left aside. The individual and its social world are continually iterating one another. The connections between these two typological categories are so substantial that, in practice, they cease to be separable entities.

With this, an image is created of a circular, mutually constituting relationship between subject, society, culture, and nature. It would be more accurate, in fact, to describe these interrelated spheres as one substance. This substance is described in terms of the Heart of Heaven/Heart of Earth relationship in Maya cosmovision. Similar unities are implied in Andean and Garifuna insistences that the people cannot be conceived of separately from the land, and that development should be culturally defined. In the interest of generalizability, and in recognition that many indigenous cosmologies around the globe contain a similar concept, the term naturacultura will be used hereon to refer to this.

The world that is assumed at the base of indigenous sustainable development is one in which the naturacultura is continually shifting. One could easily misinterpret this as a suggestion of an unstable postmodern world, the structure of which can shift at any moment at the whimsy of social imagination. This would be a misrepresentation, however. Naturacultura is always embedded in a history that structures the possibility of its form. It is highly path-dependent. Any change in it must be iterative-built onto the past, not in denial of it. Policies that are devised 
to direct this iteration can only be imagined in relation to it, and they must resonate with it to have impact.

Andean, Garifuna, and Maya thinkers and practitioners are vitally aware of power in this relationship, however. Being a constructivist theory at its root, the vision of power contained in indigenous sustainable development is generative and productive. It works to create conceptions of the world and-due to the fact of naturacultura-it shapes that world itself. This idea of power, it should be noted, is not dissimilar to those concepts generally associated with the French theorist Michele Foucault. And, as was Foucault, indigenous thinkers are aware that economic, political, and cultural power tends to congeal-that it is not equally distributed. The structural form of naturacultura has very much been determined by the power relations suggestive of a colonial and neocolonial history, by racism, patriarchy, and physical and symbolic variants of violence. Given this, the degree of environmental degradation and indigenous marginalization that exists in Latin America should not come as a surprise.

In practice, indigenous sustainable development involves attempts to build multiple physical, political, and cultural capacities in a culturally applicable way. This requires direct support for indigenous institutions such as the indigenous mayorship of Maya communities. In Ecuador, it involves the rewriting of the constitution to contain elements of Sumak Kawsay. In the predatory state of Honduras, this involves struggles for Garifuna autonomy and food sovereignty. Official integration of such institutions into more mainstream regional, national, and international governance and legal frameworks is vitally important to this goal. This can be achieved through articulation with both legal instruments and social movements on these various levels. In other words-the goal is to build social capital by facilitating the networking of indigenous institutions with a myriad of other entities such as national governance structures, political parties, media, international NGOs, and social movements on all levels.

Indigenous development movements do not just seek to increase awareness and visibility of indigenous institutions, however. Beyond this, they seek to increase the recognition and sense of legitimacy attached to these institutions - in both the eyes of external actors and members of their own communities. This might be framed as a project to build what Pierre Bourdieu (2005) has called cultural capital, or what Taylor (1995) called the terms of recognition. It involves a valorization, or an increase of the respect attached to indigenous culture, institutions, and practices. This recognition is vital in increasing what Appadurai (2004) has called the 
capacity to aspire. Recognition means that indigenous institutions can function more effectively in asserting claims. It also means that these claims can be asserted in a way that is culturally relevant to the communities involved. This, so the argument goes, would lead to a sense of empowerment where members of the local community gain the ability to credibly imagine and enact the steps that are necessary to improve their conditions.

Increases in both social and cultural forms of capital, however, are not thought to be sufficient in the pursuit of culturally sustainable development. Andean, Garifuna, and Maya leaders all insist via alternative wordings that social capital and cultural capital cannot be built independently of physical capital-especially in the form of land and related natural resources. It is not reasonable to expect poor Garifuna or Kechwa who work most of their waking hours in handicrafts production, as farm labour, or in other facets of the informal economy, to also invest serious energy in local governance and in participating in community groups.

The sustainability of such groups in the face of material constraints was the largest single problem voiced by the Maya organizers of El Centro as well. Put simply, the time expended on work necessarily undertaken by community members in the interest of survival on the most basic of levels often makes the building and maintenance of social and cultural capital almost impossible. Access to land as well as proceeds from (and control over) natural resources such as gold deposits are necessary if any meaningful pursuit of culturally sustainable development is to be undertaken. Like naturacultura itself, the elements of social, cultural, and physical capital are mutually reinforcing.

As anthropologist Charles Hale (2004) has suggested, the hegemonic neoliberal global political economy does not conceptually blend physical resources with social and cultural ones, as Maya, Garifuna, or Kechwa activists do. Neoliberal multiculturalism has an ability to tolerate rights to cultural expression and political voice, and to prevent discrimination. When indigenous peoples make appeals to rights to physical resources, however, neoliberal multiculturalism reaches its limits of tolerance. For the indigenous leaders, intellectuals, activists, and rights educators, these limits of neoliberal multiculturalism can have stark implications. El Centro Pluricultural para la Democracia, the focal point of the Maya case in this book, was placed on a national list of terrorist organizations, its funding was subsequently revoked, and it was eventually dismantled. Indigenous rights education programmes of El Centro came to be seen by foreign capital and the Guatemalan business elite as a threat to profits. Garifuna 
rights and environmental activists continue to be targets of state suppression in Honduras. Finally, as the Yasuni-ITT initiative illustrated, indigenous rights cannot insulate lands from extractive exploitation even in a country with one of the world's most progressive constitutions.

\section{Practicing Indigenous Sustainable Development}

Building social, cultural, and physical capital is the core of indigenous sustainable development. This capital formation can be pursued through education programmes and the establishment of community working groups. Indigenous sustainable development should be utilized by development practitioners, sympathetic academics, or active citizens only under certain circumstances, however. First of all, a cultural revivalist movement must preexist in a particular community-it cannot be conjured as the romanticization of a well-meaning outsider. As in the Maya case, this movement must have evolved to solve current problems and not simply for the valorization of antiquated culture. Indigenous sustainable development is only possible where things like environmental sustainability and gender equality are held as primary components of development.

This is often the case with indigenous movements. As with the Maya, Kechwa, and Garifuna, many of these search for traces of environmentalism and gender equality in their own cultural histories. They then centralize these cultural traits in the iteration of a new indigenous cultural form. New ideas attach themselves to old cultural traits within these movements to create something newer still. But, just as with the cases in this book, these programmes are rarely simply cultural-they are material as well. Physical resources are linked to cultural realities. Access to land is especially important in most indigenous movements and should be an essential component of any indigenous sustainable development programme as well.

In assisting such movements, practitioners, citizens, or sympathetic academics could do a number of things. First, since the provision of material resources is essential in such projects, development assistance funding should be pursued. So too should access to land for nutritional, economic, and cultural subsistence. Further on this point, assistance in the prevention of degradation of communal lands by outside agents such as mining or tourism companies is in the spirit of indigenous sustainable development-since the degradation of the land is also thought to degrade the culture, not to mention the health of the community. Working with groups 
to ensure that cultural revivalism projects include components that centralize equality, environmental protection, and access to land is paramount.

If these things are all in place, practitioners and policymakers must then take a hands-off, supportive approach. Indigenous sustainable development projects must be self-driven. The idea is for development to be pursued via cultural systems of understanding that exist in the community. The well-intentioned assertion of a romanticized ideal of indigenous culture or attempts to impart purified modern rationality on indigenous communities will not work. The content of an indigenous sustainable development programme must be internally sourced-it must find its fuel in the transmodern reality of local culture.

This should not present itself as a foreign idea to university-trained academics, policy analysts, or development practitioners. There are many components in that culture too that could be centralized in the interest of pursuing and understanding indigenous sustainable development. It was argued in this book that the most innovative current trends of thought in development thinking already do this. These trends were typified as cultural political economy approaches to development. The goal in such approaches is building the capacities of communities and individuals to assert their will and ideas in a more equitable environment, and thus reinforcing the capacity to aspire (Appadurai 2004) of such entities through programmatic attempts to create an equality of agency (Rao \& Walton 2004).

Analysts whose intellectual tradition comes more from economics than the other social sciences might find a resonance with indigenous sustainable development in newer nonlinear theories such as those of the complexity sciences (Urry 2005; Colander 2000; Bowles 1998) and cultural theory (Williams 1977; Kaufman 2004). They might also look to the "old" institutional economics of Veblen (1899/1994), Dusenberry (1949), and the foundational work of Adam Smith (1759/1790).

The policy implications of indigenous sustainable development could be dramatic in some ways, particularly to development economists. Arguments that free markets be embraced as the most efficient means of ensuring material development would become nonsensical, since the fundamental theoretical premise on which such ideas stand-a stable and sovereign homo economicus - would have to be abandoned. The old habit of measuring development in absolute quantitative terms such as GNP per capita would cease to make sense since well-being would need to be measured relatively and qualitatively. Importantly, a shift should take place from defining development in terms of output to defining it in terms of 
equality. That is to say that indigenous sustainable development projects would seek to ensure that the naturacultura is used and recreated in a democratic way by the humans that both compose and are composed of it. This would ensure the most efficient allocation of resources given that equality in the composition and maintenance of naturacultura is the goal instead of crude aggregated economic output.

I have been speaking of this point about the implications of indigenous sustainable development to issues in what is often called the developing world, the Third World, or the Global South. A suggestion was made in the introduction of this book, however, that the idea might have value to a larger society that needs to think its way out of substantial large-scale social, economic, and environmental predicaments. Certainly, conflict that is rooted in reified nationalisms and essentialized ethnicities remains commonplace throughout the globe-whether we are referring to wellpublicized (an often reified) tensions between Islam and the West, or ethnic and nationalistic conflicts in places such as Sudan, Kashmir, Somalia, and Yemen. Perhaps the non-essentialized view of culture used by indigenous thinkers might contain a fragment of thought that could help inform attempts to solve such serious and persistent conflicts.

The constant threatening global economic crises that have been indicative of life in the twenty-first century may also be addressed somewhat by these ideas. If economic instability has stemmed from increased debt levels in the advanced economies, and if this increased debt is the tangible result of competitive consumer cultures that have become unmoored from the natural environment to which all consumption is ultimately tied (Schor 2005), then indigenous cosmovision may be of some help. The ideals of both discursive and material equality that are embedded in indigenous ideas, along with the rejection of overly powerful Western media, could reduce the need for competitive consumption in general, if we allow, as Veblen (1899/1994) and Frank (1985) suggest that consumption is fuelled by drives towards relative wealth and its display as opposed to absolute measures.

Considering the Latin American indigenous development programmes discussed in this book leads to an important, and obvious, conclusion: to speak of indigenous development is to speak of sustainable development. Garifuna, Maya, and Andean groups do not conceptually separate nature from the human community. They also utilize a holistic concept of development. To improve the welfare of the community, from these perspectives, is to improve the health of the natural 
environment. Development that disrupts, or fails to repair, harmony between the human community and environment, cannot be defined as development from such perspectives.

This creates an imperfect fit between indigenous development and the United Nation's Sustainable Development Goals (SDGs) - the most notable mainstream development programme that considers both environment and development. Listing the 17 SDGs separately, or choosing one or two to focus on, is common practice amongst researchers, practitioners, and policymakers who prioritize mainstream sustainable development. The separation, or singling out, of any SDG, however, is in conflict with the indigenous, holistic vision of development. All must be considered at once to resonate properly with indigenous concepts.

A further issue is that two SDGs do not make sense within indigenous cosmology. SDG 8 Decent Work and Economic Growth, lists in its title two elements that are not necessary for indigenous sustainable development. Indigenous perspectives have a close resonance with de-growth or nogrowth development and often see economic growth as harmful to healthy communities and environments. Work in formal labour markets sits equally uncomfortably, although work redefined to mean activity taken to benefit the family, environment, or community may resonate with indigenous thought.

Equally problematic is SDG 9 Industry and Infrastructure. To resonate with indigenous sustainable development ideas, both of these elements would have to be defined in ways that prioritize community and environmental wellness as opposed to economic growth. Oil extraction attempts in the Yasuni National Park, gold mining in Maya territory, and tourism infrastructure projects in Garifuna lands have all failed local indigenous communities and their natural environments. Unless directed by indigenous communities themselves, and subsumed in their own cosmovisions, industry and infrastructure projects are likely to diminish community and environmental well-being. Thus SDG 9 can often make little functional sense from an indigenous perspective.

Indigenous ideas could be used to guide SDG implementation and global economic policy towards more holistically sustainable outcomes, however. The concept that nature and culture are inseparable implies a reinstated cultural connection to the natural environment and its preservation. Greater discursive and material equality may encourage the easing of competitive consumption. This could go a long way in easing the impact of human behaviour on the natural world. The incorporation of such ideas 
into mainstream models, policies, and proposals could be effective in ushering the globe in the direction of a truly sustainable human and ecological future.

\section{REFERENCES}

Appadurai, A. (2004). The Capacity to Aspire: Culture and the Terms of Recognition. In V. Rao \& M. Walton (Eds.), Culture and Public Action (pp. 59-84). Stanford: Stanford University Press.

Bourdieu, P. (2005). Principles of an Economic Anthropology. In The Social Structures of the Economy (pp. 193-222). Cambridge: Polity.

Bowles, S. (1998). Endogenous Preferences: The Cultural Consequences of Markets and Other Economic Institutions. Journal of Economic Literature, $36(1), 75-111$.

Colander, D. (2000). Complexity and the History of Economic Thought. London: Routledge.

Dusenberry, J. S. (1949). Income, Saving and the Theory of Consumer Behavior. Cambridge, MA: Harvard University Press.

Frank, R. H. (1985). Choosing the right pond: Human behavior and the quest for status. Oxford University Press.

Hale, C. (2004). Rethinking Indigenous Politics in the Era of the "Indio Permitido". NACLA Report on the Americas, 38(2), 16-22.

Kaufman, J. (2004). Convergence Culture. New York: New York University Press.

Rao, V., \& Walton, M. (2004). Culture and Public Action: Relationality, Equality of Agency, and Development. In V. Rao \& W. Walton (Eds.), Culture and Public Action (pp. 3-36). Stanford: Stanford University Press.

Schor, J. B. (2005). Sustainable consumption and worktime reduction. Journal of Industrial Ecology, 9(1-2), 37-50.

Smith, A. (1759/1790). The Theory of Moral Sentiments. London: A. Millar.

Taylor, C. (1995). The Politics of Recognition. In Philosophical Arguments. Cambridge, MA: Harvard University Press.

Urry, J. (2005). The Complexity Turn. Theory, Culture and Society, 22(5), 1-14.

Veblen, T. (1899/1994). The Theory of the Leisure Class. New York: Dover Publications.

Williams, R. (1977). Marxism and Literature. Oxford and New York: Oxford University Press. 
Open Access This chapter is licensed under the terms of the Creative Commons Attribution 4.0 International License (http://creativecommons.org/licenses/ by $/ 4.0 /$ ), which permits use, sharing, adaptation, distribution and reproduction in any medium or format, as long as you give appropriate credit to the original author(s) and the source, provide a link to the Creative Commons licence and indicate if changes were made.

The images or other third party material in this chapter are included in the chapter's Creative Commons licence, unless indicated otherwise in a credit line to the material. If material is not included in the chapter's Creative Commons licence and your intended use is not permitted by statutory regulation or exceeds the permitted use, you will need to obtain permission directly from the copyright holder. 